\title{
Penerapan Sistem Pakar Dalam Pengembangan Budidaya Padi Teknologi Salibu Dengan Metode Forward Chaining
}

\author{
Ullya Mega Wahyuni \\ Universitas Putra Indonesia "YPTK" Padang \\ ullya.mw@gmail.com
}

\begin{abstract}
Abstrak
Seiring dengan berkembangnya teknologi, maka peran dari teknologi informasi semakin berguna untuk berkembang di berbagai bidang termasuk pada bidang pertanian. Salah satunya yaitu sistem yang digunakan untuk membantu pengembangan padi Salibu, penelitian ini bertujuan untuk membuat desain aplikasi Sistem Pakar budidaya padi Salibu berbasis web. Dalam penelitian ini metode yang digunakan untuk membuat Sistem Pakar padi Salibu yaitu menggunakan metode Forward Chaining. Pada metode Forward Chaining, proses pencarian data dimulai dari premis menuju kesimpulan akhir. Metode ini juga disebut data driven yaitu pencarian dikendalikan oleh data yang diberikan. Hasil akhir yang diperoleh dari penelitian ini adalah sebuah Apikasi Sistem Pakar identifikasi lahan padi Salibu dengan metode Forward Chaining, dimana user atau pengguna memasukkan data berupa kondisi lahan yang terlihat sesuai yang terdapat pada pilihan, lalu hasil yang diperoleh berupa kesimpulan kondisi lahan, serta teknik atau tata cara pelaksanaan teknologi Salibu.
\end{abstract}

Kata Kunci : Sistem Pakar, Forward Chaining, Pertanian, Padi Salibu

\section{PENDAHULUAN}

Pertanian merupakan salah satu sektor industri yang mempunyai peranan penting dalam kehidupan manusia. Program ketahanan pangan di Indonesia masih bertumpu pada komoditas padi sawah, namun permasalahan paling mendasar adalah kepemilikan lahan yang sempit sehingga usaha tani padi sawah kurang efesien. Untuk itu perlu terobosan teknologi dalam meningkatkan produktifitas dan efesiensi usaha tani padi sawah.

Teknologi padi Salibu merupakan tanaman padi yang tumbuh kembali setelah batang sisa panen dipangkas. Tunas baru akan muncul dari buku yang ada di dalam lahan. Teknologi ini berawal dari inovasi dan kreativitas petani di Nagari Tabek Pariangan Kabupaten Tanah Datar (Erdiman et al, 2014).

Tahapan utama dalam budidaya Salibu yaitu persiapan lahan. Penggunaan lahan yang tidak sesuai dalam Budidaya Padi Teknologi Salibu dapat menyebabkan kegagalan dalam proses bercocok tanam petani. Menurut Hardjowigeno, evaluasi kesesuaian lahan dilakukan dengan cara membandingkan persyaratan penggunaan lahan dengan kualitas (karakteristik) lahannya (Carlos Samuel et al, 2013). Untuk menyelesaikan masalah dalam penentuan kesesuian lahan tersebut perlu di bangun sistem yang memakai metode inferensi Forward Chaining, karena metode Forward Chaining melakukan pencarian atau penarikan kesimpulan yang berdasarkan pada data atau fakta yang ada menuju ke kesimpulan.

Menurut Eliza (2010) dalam pengelolaan berbagai hambatan yang dihadapi petani seperti penguasaan teknologi budidaya, penggunaan faktor produksi yang tidak sesuai dengan rekomendasi, pengetahuan dan keterampilan manusia yang terbatas akan berpengaruh terhadap produktifitas.

Untuk mengatasi permasalahan tersebut dibutuhkan sebuah apilikasi berbasis web. Keberadaan internet yang memungkinkan sistem diakses secara online, akan dapat membantu petani untuk menentukan kesesuaian lahan mereka. Kehadiran sistem pakar online ini juga akan dapat membantu proses penyebaran informasi dan pengetahuan melalui 
aplikasi yang dapat diakses kapan saja dan dimana saja, serta dapat menjangkau daerah yang lebih luas

\section{KAJIAN LITERATUR}

Menurut Sutojo (2011), Sistem Pakar merupakan suatu sistem yang dirancang untuk dapat menirukan keahlian seorang pakar dalam menjawab pertanyaan dan memecahkan suatu masalah. Sistem Pakar akan memberikan pemecahan suatu masalah yang didapat dari dialog dengan pengguna. Dengan bantuan Sistem Pakar seseorang yang bukan pakar/ahli dapat menjawab pertanyaan, menyelesaikan masalah serta mengambil keputusan yang biasanya dilakukan oleh seorang pakar.

Sistem Pakar disusun oleh dua bagian utama, yaitu lingkungan pengembangan (development environment) dan lingkungan konsultasi (consultation environment) (Sutojo et $a l$, 2011). Lingkungan pengembangan Sistem Pakar digunakan untuk membangun komponen-komponennya dan memperkenalkan pengetahuan ke dalam knowledge base (basis pengetahuan). Lingkungan konsultasi digunakan untuk berkonsultasi sehingga pengguna mendapatkan pengetahuan dan nasihat dari Sistem Pakar layaknya berkonsultasi dengan seorang pakar. Untuk membangun sistem yang seperti itu, dibutuhkan komponenkomponen sebagai berikut:

1. Basis pengetahuan (Knowledge base). Berisi pengetahuan-pengetahuan yang dibutuhkan untuk memahami, memformulasikan dan memecahkan persoalan. Bentuk basis pengetahuan yang umum digunakan ada 2, yaitu: penalaran berbasis aturan dan penalaran berbasis kasus.

2. Motor inferensi (inference engine). Ada 2 cara yang dapat dikerjakan dalam melakukan inferensi, yaitu:

a. Forward chaining merupakan grup dari multiple inferensi yang melakukan pencarian dari suatu masalah kepada solusinya. Forward chaining adalah datadriven karena inferensi dimulai dengan informasi yang tersedia dan baru konklusi diperoleh. Pencocokan fakta atau pernyataan dimulai dari bagian sebelah kiri (IF dulu). Dengan kata lain, penalaran dimulai dari fakta terlebih dahulu untuk menguji kebenaran hipotesis. Gambar 1 berikut menunjukkan diagram Forward chaining.

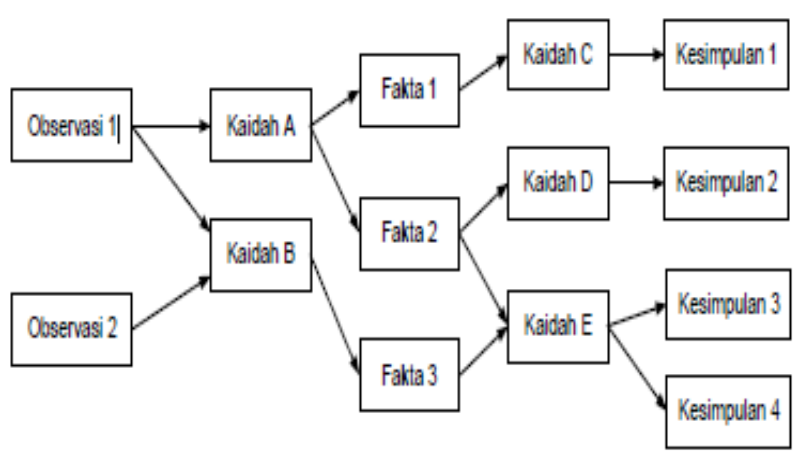

Gambar 1. Diagram Forward Chaining

b. Backward chaining menggunakan pendekatan goal-driven, dimulai dari ekspektasi apa yang diinginkan terjadi (hipotesis), kemudian mencari bukti yang mendukung (atau kontradiktif) dari ekspektasi tersebut. Pencocokan fakta atau pernyataan dimulai dari bagian sebelah kanan (THEN dulu). Dengan kata lain, penalaran dimulai dari hipotesis terlebih dahulu, dan untuk menguji kebenaran hipotesis tersebut harus dicari fakta-fakta yang ada dalam basis pengetahuan. Gambar 2 berikut menunjukkan diagram Backward chaining. 


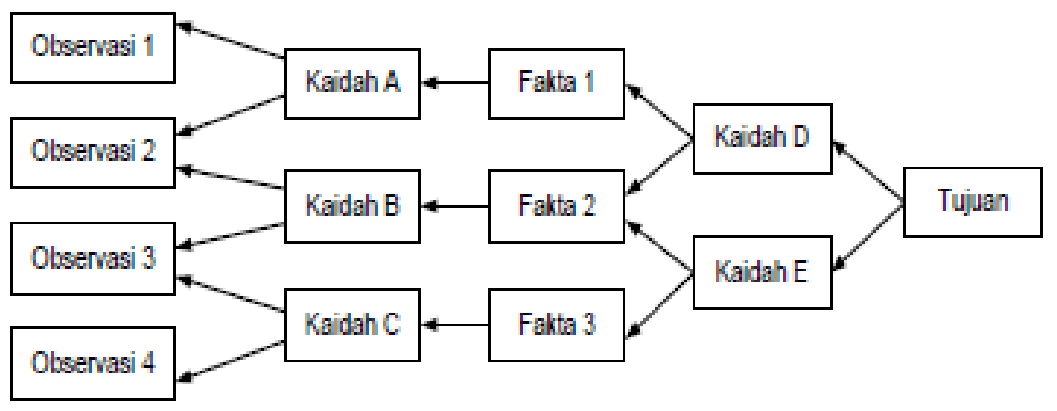

\section{Gambar 2.Diagram Backward Chaining}

3. Blackboard. Merupakan area kerja memori yang disimpan sebagai database untuk deskripsi persoalan terbaru yang ditetapkan oleh data input dan digunakan juga untuk perekaman hipotesis dan keputusan sementara.

4. Subsistem akuisisi pengetahuan. Akuisisi pengetahuan adalah akumulasi, transfer, dan transformasi keahlian pemecahan masalah dari pakar atau sumber pengetahuan terdokumentasi ke program komputer untuk membangun atau memperluas basis pengetahuan.

5. Antarmuka pengguna (User Interface). Digunakan untuk media komunikasi antara user dan program.

6. Subsistem penjelasan. Digunakan untuk melacak respon dan memberikan penjelasan tentang kelakuan sistem pakar secara interaktif melalui pertanyaan.

7. Sistem penyaring pengetahuan.

Untuk lebih jelasnya, komponen sistem pakar dapat dilihat pada Gambar 3.

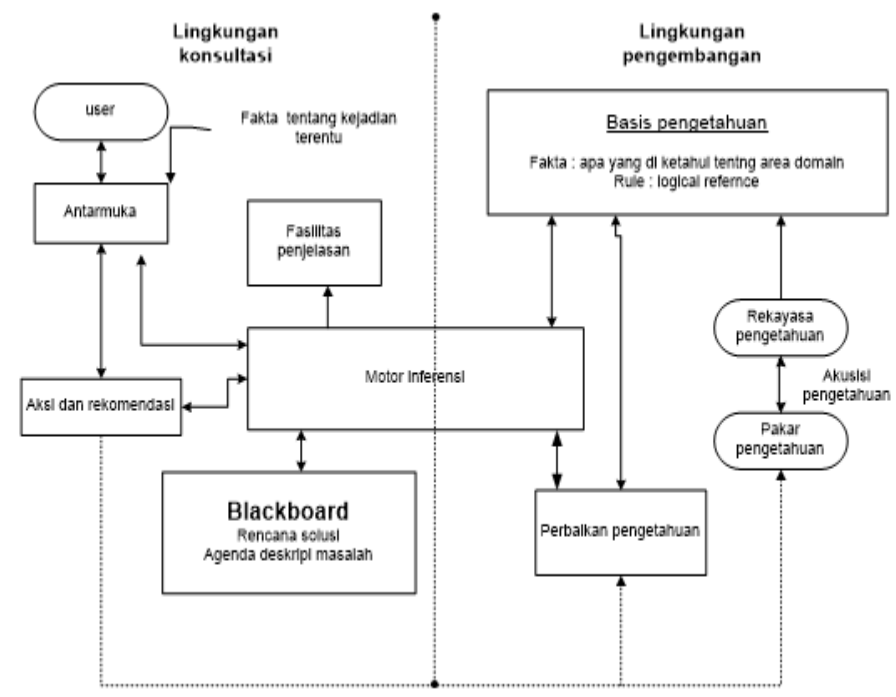

Gambar 3. Komponen Sistem Pakar

Dari komponen-komponen sistem pakar di atas, secara garis besar ada 3 komponen utama, yaitu: basis pengetahuan, mesin inferensi, dan antarmuka pengguna (Daniel dan Virginia, 2010).

Terkait dengan komponen rule base, kaidah produksi yang biasa dikenal rule base (basis aturan) ini menjadi acuan yang sangat sering digunakan oleh sistem inferensi. Kaidah produksi ini merupakan

salah satu model untuk merepresentasikan pengetahuan (knowledge base). Kaidah produksi merupakan kumpulan kaidah-kaidah yang saling berhubungan satu sama lain (Fattah dan Wibowo,2010). Kaidah produksi dituliskan dalam bentuk 
pernyataan IF-THEN (Jika-Maka). Pernyataan ini menghubungkan bagian premis $(I F)$ dan bagian kesimpulan (THEN) yang dituliskan dalam bentuk :

IF [premis] THEN [konklusi]

Jadi, kaidah ini dapat dikatakan sebagai suatu implikasi yang terdiri dari dua bagian, yaitu premis dan bagian konklusi. Apabila bagian premis dipenuhi maka bagian konklusi akan bernilai benar.

Bagian premis dalam aturan produksi dapat memiliki lebih dari satu proposisi. Proposisiproposisi tersebut dihubungkan dengan menggunakan operator logika AND atau $O R$.

\section{METODE PENELITIAN}

Pada penelitian ini, metode yang digunakan yaitu metode forward chaining yang diimplementasikan untuk dapat membantu petani untuk menentukan kesesuaian lahan mereka dalam budidaya padi teknologi Salibu yang dapat dilihat pada gambar 4 berikut.

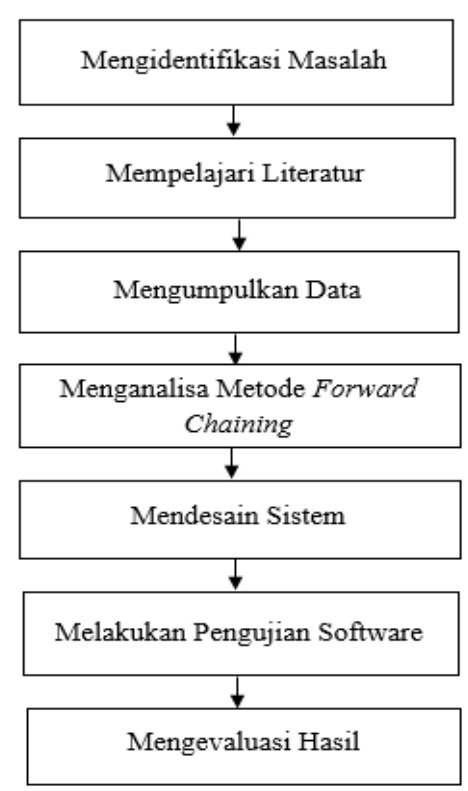

\section{Gambar 4. Kerangka Kerja Penelitian}

Berdasarkan kerangka kerja pada gambar 4 dimulai dengan mengidentifikasikan masalah yaitu memperhatikan fakta-fakta morfologi yang ada dilahan dan pemilihan akuisisi pengetahuan. Selanjutnya menganalisa masalah, peneliti melakukan beberapa cara dan metode di antaranya metode deskriptif. Pada metode ini data yang akan dikumpulkan, disusun, dianalisa sehingga diperoleh beberapa gambaran yang jelas pada masalah penelitian. Kemudian melakukan studi literatur dan mengumpulkan data primer dengan cara interview dengan Pakar padi Salibu. Metode yang digunakan dalam pembangunan sistem ini adalah metode forward chaining, yang dimulai dari sekumpulan fakta-fakta tentang kondisi lahan yang telah diamati user sebagai masukan (input) sistem untuk kemudian dilakukan pelacakan sampai tercapainya tujuan akhir berupa kesimpulan. Tahap selanjutnya yaitu desain sistem dimana dari penyusunan basis data, basis pengetahuan, mesin referensi yaitu forward chaining dan perancangan interface dan mulai dengan implementasi sistem. Tahap terakhir yaitu evaluasi hasil berupa kesimpulan dan saran. 


\section{HASIL DAN PEMBAHASAN}

Arsitektur Sistem Pakar untuk menentukan lahan yang tepat untuk budidaya padi Salibu mempunyai enam komponen utama yang dapat didesain seperti gambar 5:

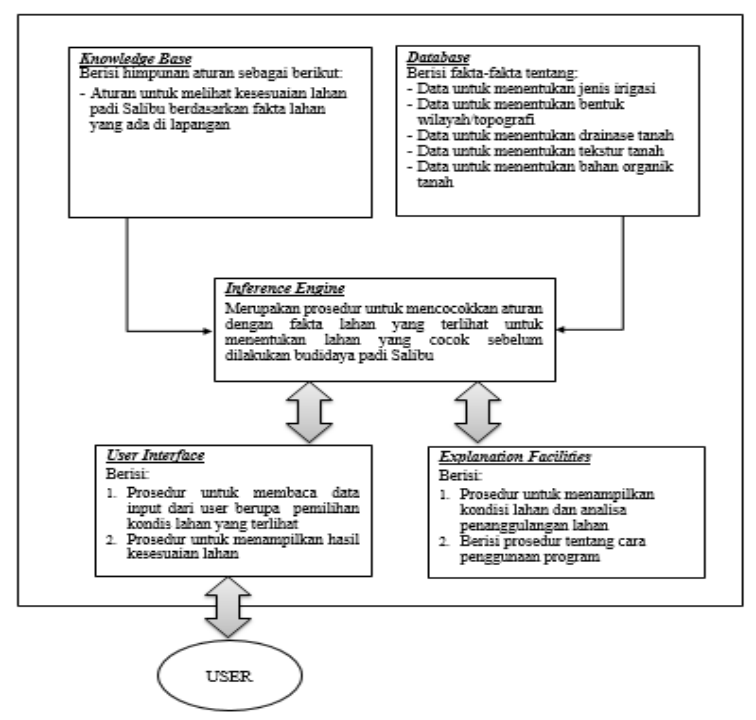

Gambar 5. Desain Arsitektur Sistem Pakar

\section{Basis Pengetahuan (Knowledge Base)}

Dalam penelitian ini, knowledge base terdiri dari dua elemen dasar yaitu fakta dan rules. Pada kasus ini perlu memasukkan fakta-fakta yang dibutuhkan oleh Sistem Pakar untuk melakukan proses, yang menjadi fakta dalam identifikasi lahan padi Salibu berupa faktorfaktor secara umum yang mempengaruhi dalam penentuan lahan yang terlihat pada gambar 6.

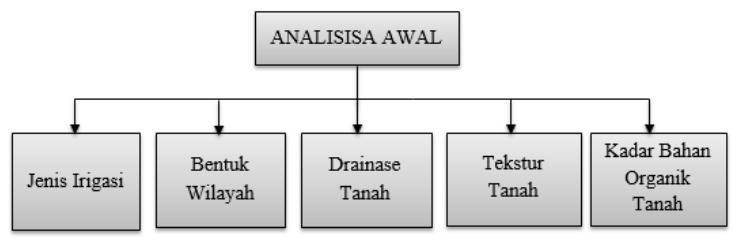

Gambar 6. Faktor-Faktor Yang Mempengaruhi Lahan

Untukmerepresentasikan pengetahuan Sistem Pakar akan menampilkan pilihan jenis irigasi, bentuk wilayah/topografi, drainase tanah, tekstur tanah, dan bahan organik tanah, pilihan yang diberikan oleh user akan disimpan sebagai fakta di database.

Untuk mendukung penalaran dalam menentukan lahan yang tepat sebelum dilakukan budidaya padi teknologi Salibu, maka pengetahuan yang diperoleh dari pakar dapat direpresentasikan dalam bentuk pohon keputusan. Tree yang digunakan pada masalah evaluasi lahan merupakan suatu forward chaining tree. Pada forward chaining tree penelusuran informasi dilakukan secara forward (ke depan) seperti yang umumnya digunakan pada masalah-masalah lainnya. Dari kondisi lahan yang diketahui, kemudian dilakukan penelusuran kedepan untuk mencari fakta-fakta yang cocok berupa faktor-faktor yang mempengaruhi lahan. Pada diagram decision tree tersebut dapat dilihat bahwa bagaimana beberapa fakta lahan yang sama dapat merujuk kepada beberapa kesimpulan yang berbeda. Untuk lebih jelasnya, decision tree dapat dilihat pada gambar 7. 
$1412-5854$

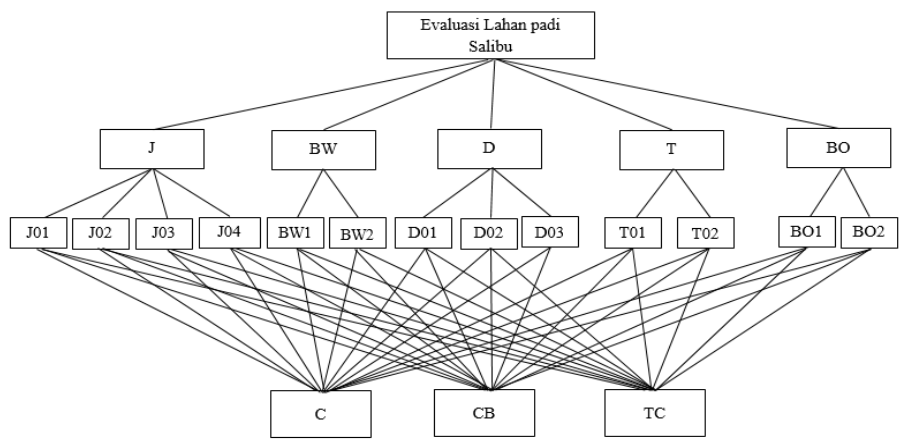

Gambar 7. Diagram Decision Tree Evaluasi Lahan Padi Salibu

Berikut keterangan dari gambar 7 yang dapat dijelaskan pada tabel 1.

Tabel 1. Keterangan Penalaran Keputusan Evaluasi Lahan Padi Salibu

\begin{tabular}{|c|l|}
\hline KODE & \\
\hline C & Cocok \\
\hline CB & Cocok Bersyarat \\
\hline TC & Tidak Cocok \\
\hline J & Jenis Irigasi \\
\hline BW & Bentuk Wilayah \\
\hline D & Drainase Tanah \\
\hline T & Tekstur Tanah \\
\hline BO & Kadar Bahan Organik Tanah \\
\hline J01 & Irigasi Teknis \\
\hline J02 & Irigasi 1 2 Teknis \\
\hline J03 & Irigasi Pompa \\
\hline J04 & Irigasi Tadah Hujan \\
\hline BW1 & Bentuk Wilayah Miring \\
\hline BW2 & Bentuk Wilayah Datar \\
\hline D01 & Drainase Tanah Lancar \\
\hline D02 & Drainase Tanah Agak Terhambat \\
\hline D03 & Drainase Tanah Terhambat \\
\hline T01 & Tekstur Tanah Sedang-Halus \\
\hline T02 & Tekstur Tanah Kasar \\
\hline BO1 & Kadar Bahan Organik Tanah Cukup \\
\hline BO2 & Kadar Bahan Organik Tanah Kurang \\
\hline & \\
\hline
\end{tabular}

Setelah dibuat decision tree dengan metode forward chaining, maka disusun daftar aturan (rule) yang dapat dilihat pada tabel 2.

Tabel 2 Daftar Aturan

\begin{tabular}{|c|l|}
\hline NO & \multicolumn{1}{|c|}{ ATURAN $($ RULE $)$} \\
\hline 1 & $\begin{array}{l}\text { IF Jenis Irigasi="Teknis" AND Bentuk } \\
\text { wilayah="Miring" AND Drainase } \\
\text { tanah="Lancar" AND Tekstur } \\
\text { tanah="Sedang-halus" AND Kadar bahan } \\
\text { organik tanah="Cukup" Then } \\
\text { Lahan="Cocok" }\end{array}$ \\
\hline 2 & $\begin{array}{l}\text { IF Jenis Irigasi="Teknis" AND Bentuk } \\
\text { wilayah="Miring" AND Drainase } \\
\text { tanah="Lancar" AND Tekstur } \\
\text { tanah="Sedang-halus" AND Kadar bahan } \\
\text { organik tanah=Kurang" Then } \\
\text { Lahan="COcok" }\end{array}$ \\
\hline 3 & IF Jenis Irigasi="Teknis" AND Bentuk \\
\hline
\end{tabular}




\begin{tabular}{|c|c|}
\hline & $\begin{array}{l}\text { wilayah="Miring" AND Drainase } \\
\text { tanah="Lancar" AND Tekstur } \\
\text { tanah="Kasar" AND Kadar bahan organik } \\
\text { tanah="Cukup" Then Lahan="Cocok" }\end{array}$ \\
\hline 4 & $\begin{array}{l}\text { IF Jenis Irigasi="Teknis" AND Bentuk } \\
\text { wilayah="Miring" AND Drainase } \\
\text { tanah="Lancar" AND Tekstur } \\
\text { tanah="Kasar" AND Kadar bahan organik } \\
\text { tanah="Kurang" Then Lahan="Cocok } \\
\text { Bersyarat" }\end{array}$ \\
\hline 5 & $\begin{array}{l}\text { IF Jenis Irigasi="Teknis" AND Bentuk } \\
\text { wilayah="Miring" AND Drainase } \\
\text { tanah="Agak terhambat" AND Tekstur } \\
\text { tanah="Sedang-halus" AND Kadar bahan } \\
\text { organik tanah="“Cukup" Then } \\
\text { Lahan="Cocok" }\end{array}$ \\
\hline 6 & (1) \\
\hline 82 & $\begin{array}{l}\text { IF Jenis Irigasi=" Tadah hujan" AND Bentuk } \\
\text { wilayah="Datar" AND Drainase } \\
\text { tanah="Agak terhambat" AND Tekstur } \\
\text { tanah="Sedang-halus" AND Kadar bahan } \\
\text { organik tanah="Kurang" Then } \\
\text { Lahan="Tidak cocok" }\end{array}$ \\
\hline 83 & $\begin{array}{l}\text { IF Jenis Irigasi=" Tadah hujan" AND Bentuk } \\
\text { wilayah="Datar" AND Drainase } \\
\text { tanah="Agak terhambat" AND Tekstur } \\
\text { tanah="Kasar" AND Kadar bahan organik } \\
\text { tanah="CCukup" Then Lahan="Tidak cocok" }\end{array}$ \\
\hline 84 & $\begin{array}{l}\text { IF Jenis Irigasi=" Tadah hujan" AND Bentuk } \\
\text { wilayah="Datar" AND Drainase } \\
\text { tanah="Agak terhambat" AND Tekstur } \\
\text { tanah="Kasar" AND Kadar bahan organik } \\
\text { tanah="Kurang" Then Lahan="Tidak cocok" }\end{array}$ \\
\hline
\end{tabular}

\section{Analisa Database}

Analisa data adalah proses mendefinisikan semua kebutuhan data agar sistem dapat berjalan lancar dengan baik. Pada Sistem Pakar ini menggunakan konsep relational database yang berisi kumpulan tabel dalam satu file yang saling berinteraksi satu dengan yang lainnya, di mana setiap tabel mempunyai nama dan struktur yang unik. Dalam setiap tabel masing-masing record data diorganisasikan dalam struktur yang sama dan memiliki fields kunci yang akan menjadi penghubung antar tabel yang ada dan berkaitan satu dengan yang lainnya.

\section{Inference Engine}

Mesin inferensi merupakan otak dari Sistem Pakar, berupa perangkat lunak yang melakukan tugas inferensi penalaran Sistem Pakar, bisa dikatakan sebagai mesin pemikir (Thingking Machine). Pada prinsipnya mesin inilah yang akan mencari solusi dari suatu permasalahan. Konsep yang digunakan untuk mesin inferensi pada sistem ini adalah runut maju (Forward Chaining. Dalam kasus ini sistem pakar akan menghasilkan goal berupa identifikasi lahan yaitu: "cocok", "cocok bersyarat", dan "tidak cocok" untuk diterapkannya budidaya padi Salibu. Untuk lebih jelasnya inference enggine dapat dilihat pada gambar 8 . 


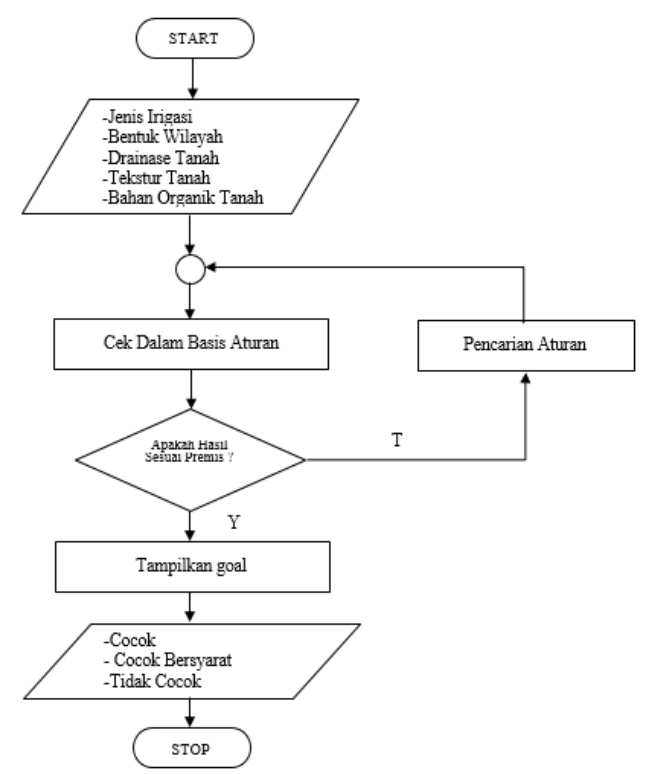

Gambar 8 Algoritma Inference Enggine

Contoh Sampel Data

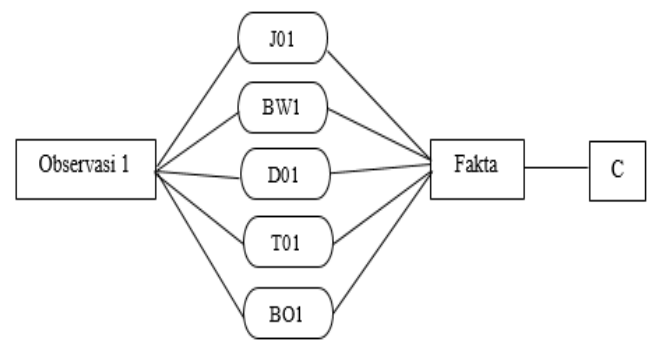

Gambar 9 Sampel Data Kondisi Lahan Cocok

Pada gambar 9 dapat dilihat sampel data yang digunakan pada sistem. Dimulai dari observasi data lahan, didapatkan fakta berupa irigasi teknis (J01), bentuk wilayah miring (BW1), drainase lancar (D01), tekstur tanah sedang/halus (T01), dan kadar bahan organik tanah cukup (BO1), maka didapatkan goal kondisi lahan dalam keadaan cocok untuk diterapkan padi teknologi Salibu.

Dari gambar 9 dapat dibuat tabel 3 sampel penelusuran metode forward chaining kondisi lahan cocok untuk budidaya padi teknologi Salibu. Dimana akan diberikan pertanyaan berupa faktor-faktor yang mempengaruhi lahan dan sistem akan memberikan hasil kesimpulan dari hasil konsultasi.

Tabel 3 Sampel Penelusuran Lahan Cocok

\begin{tabular}{|l|l|}
\hline No & \multicolumn{1}{|c|}{ Aturan (Rule) } \\
\hline 1 & IF Jenis Irigasi Teknis is True \\
& AND Bentuk wilayah Miring is True \\
& AND Drainase tanah Lancar is True \\
& AND Tekstur tanah Sedang/halus is True \\
& AND Kadar bahan organik tanah Cukup is \\
& True \\
& Then Lahan Cocok \\
\hline
\end{tabular}

Proses penelusuran forward chaining dapat dilihat sebagai berikut:

1. IF J01 Then BW1

2. IF BW1 Then $\mathrm{D} 01$

3. IF D01 Then $\mathrm{T} 01$ 


\section{GOAL 5. IF B01 Then $\mathrm{C}$}

Pada penelusuran lahan cocok, penelusuran pertama dieksekusi apabila fakta sudah cocok dengan aturan bagian IF pada bagian IF-THEN. Kemudian data tersebut menghasilkan fakta baru dibagian Then yang akan disimpan ke database. Proses penelusuran dilakukan dari rule pertama dan tidak ada pengulangan eksekusi. Proses eksekusi akan berhenti apabila tidak ada lagi data yang sesuai dan akan mengeluarkan kesimpulan berdasarkan pencocokan fakta.

\section{Explaining Facilities (Fasilitas Penjelasan)}

Fasilitas penjelasan Sistem Pakar diracang dengan tujuan untuk memberikan penjelasan kepada user bagaimana sistem pakar ini bekerja. Bentuk penjelasannya dapat berupa keterangan jenis irigasi, bentuk wilayah/topografi, drainase tanah, tekstur tanah, dan bahan organik tanah.

\section{User Interface}

Program yang akan dibangun untuk pengembangan budidaya padi Salibu ini memiliki sub-sub program yang sesuai dengan bagian dan keperluan masing-masing. Untuk mempermudah dalam penggunaan program dirancanglah struktur hirarki dari keseluruhan tampilan sistem seperti yang terlihat pada gambar 10 berikut ini.

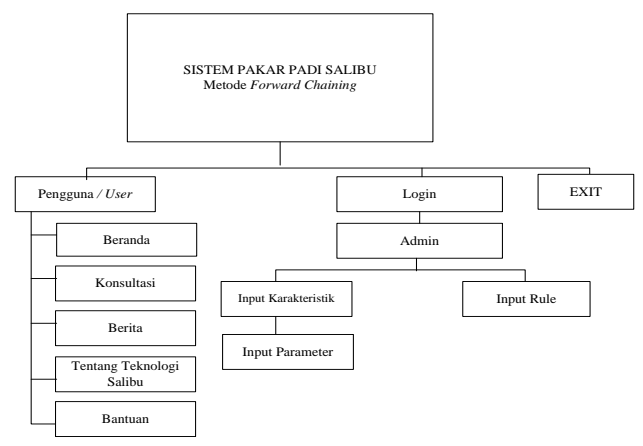

Gambar 10 Struktur Program Sistem Pakar Padi Salibu

\section{KESIMPULAN DAN SARAN}

\section{Kesimpulan}

Berdasarkan hasil penelitian dan pembahasan dapat ditarik kesimpulan sebagai berikut:

1. Penerapan metode berbasis aturan dengan proses inferensi Forward Chaining didapatkan 84 rule untuk mengidentifikasi lahan pertanian budidaya padi teknologi Salibu berdasarkan karakteristik lahan yang dimasukkan serta bisa memberikan solusi seperti layaknya seorang pakar.

2. Dari penelitian yang telah dilakukan, dihasilkan sebuah perangkat lunak (Software) baru dalam bidang pertanian berbasi web. Dengan adanya aplikasi Sistem Pakar berbasis web, pengguna dapat mengakses aplikasi tersebut di mana saja dengan lebih mudah dan praktis.

3. Berdasarkan hasil uji sistem Black Box, bahwa pada aplikasi Sistem Pakar ini bisa berjalan dengan baik dan bisa menghasilkan output yang diharapkan serta bisa dipakai pada tahap konsultasi. Penerapan metode berbasis aturan dengan proses inferensi Forward Chaining dapat menghasilkan diagnosis kondisi lahan dengan 
benar berdasarkan aturan-aturan yang telah dibuat dan berdasarkan hasil pengujian didapatkan bahwa dari karakteristik lahan yang diujikan dapat dideteksi oleh Sistem Pakar.

\section{Saran}

Dari kesimpulan - kesimpulan tersebut,maka dapat dikemukakan beberapa saran yang akan membantu untuk pengembangan sistem pakar ini selanjutnya. Adapun saran yang diusulkan yaitu:

1. Aplikasi Sistem Pakar untuk budidaya padi teknologi Salibu ini menggunakan metode Forward Chaining dan masih dapat dikembangkan lagi menggunakan metode lain. Dapat juga disertai faktor kepastian (Certainty Factor) untuk memperkuat kesimpulan.

2. Penentuan hasil identifikasi lahan untuk pengembangan budidaya padi Salibu dapat menggunakan lebih banyak parameter, dengan banyaknya parameter diharapkan dapat memberikan hasil yang lebih akurat lagi dalam identifikasi lahan.

\section{REFERENSI}

Eliza, Tarumun, S. \& Yusmini, 2010. Pengaruh Faktor Produksi Terhadap Produksi Kelapa Hibrida Pola Plasma Di Kabupaten Indragiri Hilir. Indonesian Journal of Agricultural Economics ( IJAE ), 1(1), pp.49-62.

Erdiman, Nainggolan, K. \& Harahap, I.M., 2014. Teknologi Melipatgandakan Produksi Padi Nasional. Jakarta: PT Gramedia Pustaka Utama.

Fathoni, A., 2015. Penilaian Kesesuaian Lahan Untuk Tanaman Penghijauan Di taman Kehati Unnes Trangkil Sekaran Semarang. Geo Image ( Spatial-Ecological-Regional ), 4(1), pp.1-10.

Nuraeni, F., Agustin, Y.H. \& Yusup, E.N., 2016. Aplikasi Pakar Untuk Diagnosa Penyakit Kulit Menggunakan Metode Forward Chaining Di Al Arif Skin Care Kabupaten Ciamis. Seminar Nasional Teknologi Informasi dan Multimedia, pp.6-7.

Nurzaman, Destiani, D. \& Dhamiri, D.J., 2012. Pembangunan Aplikasi Sistem Pakar untuk Diagnosis Penyakit Gigi dan Mulut Pada Manusia. Jurnal Algoritma Sekolah Tinggi Teknologi Garut, 9(12), pp.1-8.

Pardosi, E., Jamilah \& Lubis, K.S., 2013. Kandungan Bahan Organik Dan Beberapa Sifat Fisik Tanah Sawah Pada Pola Tanam Padi-Padi Dan Padi Semangka. Jurnal Online Agroekoteknolog, 1(3), pp.429-439.

Paryati, 2015. Aplikasi Farmakoterapi Sistem Pakar Berbasis Web Untuk Mendiagnosa Penyakit Syaraf Pusat. Seminar Nasional Informatika (semnasIF), pp.233-244.

Pasaribu, J.S., 2015. Implementasi Sistem Pakar Untuk Diagnosa Penyakit Mata Pada Manusia. Seminar Nasional Teknologi Informasi dan Komunikasi, pp.43-50.

Rani, P.M.N., Rajesh, T. \& Saravanan, R., 2011. Expert Systems in Agriculture : A Review. Journal of Computer Science, 3(1), pp.59-71.

Rosadi, D. \& Hamid, A., 2014. Sistem Pakar Diagnosa Penyakit Tanaman Padi Menggunakan Metode Forward Chaining. Jurnal Computech \& Bisnis, 8(1), pp.43-48.

Samuel, C., Sitorus, B. \& Supriadi, 2013. Evaluasi Kesesuaian Lahan Untuk Tanaman Apel Di Desa Sihiong Kecamatan Bonatua Lunasi Kabupaten Toba Samosir. Jurnal Online Agroekoteknologi, 1(4), pp.996-1003. 
Sinaga, Y.P.A., Razali \& Sembiring, M., 2014. Evaluasi Kesesuaian Lahan Untuk Padi Sawah Tadah Hujan (Oryza sativa L.) Di Kecamatan Muara Kabupaten Tapanuli Utara. Jurnal Online Agroekoteknologi, 2(3), pp.1042-1048.

Susanti, F. \& Winiarti, S., 2013. Sistem Pakar Penentuan Kesesuaian Lahan Pertanian Untuk Pembudidayaan Tanaman Buah-Buahan. Jurnal Sarjana Teknik Informatika, 1(1), pp.317-326.

Sutojo, T., Mulyanto, E. \& Suhartono, V., 2010. Kecerdasan Buatan. Semarang: Andi Yogyakarta.

Verina, W., 2015. Penerapan Metode Forward Chaining untuk Mendeteksi Penyakit THT. Jatisi, 1(2), pp.123-138.

Wijayanti, R. \& Winiarti, S., 2013. Sistem Pakar Mendiagnosa Penyakit Pada Buah-Buahan Pascapanen. Jurnal Sarjana Teknik Informatika, 1(1), pp.338-346.

Yadav, S.K., Singhal, N. \& Yadav, V., 2014. RICEsmart: An Expert System to Enhance Rice Yield. International Journal of Computer Science and Information Technologies (IJCSIT), 5(5), pp.68776879 . 